\title{
Opportunities and Challenges of Irrigated Crop Production in Dry Land Areas. Review
}

\author{
Girma Abebe \\ Jimma University College of Agriculture and Veterinary Medicine \\ Department of plant and horticultural sciences, Jimma \\ University, Jimma, Ethiopia, P.O. Box 307
}

\begin{abstract}
Irrigation development is very much needed in developing countries as it enhances land, water and labour productivity and improves use of agricultural inputs. Irrigated agriculture shows significant improvement over rainfed agriculture productivity it provides improved resilience against climate variability improves food security and enhances intensification. Also, with a depleting resource base and with stagnating productivity in irrigated areas, improving the productivity of dryland agriculture is necessary to maintain food security at the national scale.To improve the conditions for agricultural production, investments are needed in soil and water conservation to improve soil fertility, increase soil moisture and allow for supplemental irrigation in critical stages of growth.Generally, over 40 percent of the world area is categorized as dry-land developing countries where its accommodate 2.3 billion people mostly in Africa and Asia, and in these regions about one billion people rely on dry-land ecosystem services through rain-fed, irrigated farming and pastoralism. Dry-land areas are categorized by a scarcity of water, which has an impact on food production. Efficiency in irrigation system would help food production sustain especially in dry-land developing countries. Improvement in irrigation could be extended over an additional 110 million ha in dry-land developing countries, producing enough grain for millions of people where more than half of future increases in crop production are expected to come from irrigated land. There are two types of known irrigation systems, namely large-scale and small-scale irrigation. Most of the dryland developing countries are engaging in small-scale irrigation systems, as they are more affordable than those of large-scale systems, but are still capable of increasing food production. Water harvesting is one of the small-scale techniques of collecting runoff rain water for irrigation purposes and has significantly improved both the yield and reliability of agricultural production. The objective of this review is to examine the Opportunities and challenges of irrigated crop production in dry land developing countries. Ethiopia's dryland agriculture is a high-risk, low-input enterprise for resource-poor farmers, who frequently use poor quality seed, inadequate and imbalanced fertilizers, and poor crop management practices. Consequently, crop yields are much below their demonstrated achievable potentials. Remedial measures for improving crop productivity include effective rainwater harvesting, land consolidation, improved credit facilities, better soil and water conservation, use of good quality seed, balanced nutrient management, and weed control.
\end{abstract}

Keyword: crop Production, Land Irrigation and dry-land developing countries

DOI: $10.7176 / \mathrm{JAAS} / 71-02$

Publication date: April $30^{\text {th }} 2021$

\section{Introduction}

Globally, Irrigation has been the world oldest agricultural civilization for thousands of years ago. It has been practiced in Egypt, China, India and other parts of Asia for a long period of time for a response to bad agro climate in low rainfall areas and seasons and has been a means to bring about socioeconomic transformation since the Second World War (Hamdtulu, 2014).In Ethiopia, traditional irrigation was practiced before centuries (Bekele et al., 2012). Specially, Seed cultivation involving irrigation was introduced to Northern Ethiopia - in the era of the Axum Empire in 1000 B.C.furthermore, Modern irrigation had started at the beginning of the 1960's by private investors and was concentrated in the middle awash valley (Yalew et al, 2011).

Agriculture faces multiple challenges in the 21st century: it has to produce more food to feed a growing populationwith a smaller rural labor force, contribute to development in agriculture-dependent developing countries including Ethiopia(FAO, 2009).This fact can bring irrigation to the fore-front irrigation is increasingly recognized as a major component in economic development and poverty reduction. For a country like Ethiopia which is grappling with burgeoning population while the subsistence rainfed agriculture is under the mercy of the erratic rainfall, small scale irrigation development is believed to have an imperative role in the agricultural, socio-economic development (Abebaw,2016).

Dry-land developing countries cover 40 percent of the world's area and accommodate 2.3 billion people. Dry-land areas are most prevalent in Africa and Asia, and in these regions about one billion people rely on dryland ecosystem services through rain-fed, irrigated farming and pastoralism. Dry-land areas are categorized by a scarcity of water, which has an impact on primary production and nutrient cycling (CGIAR, 2013). Water shortages give an impact crop production, forage, and others plants, and negatively impact human bodies. The 
Food and Agriculture Organization (FAO) has defined dry land as areas in which the growing period (LGP) lasts from 1-179 days. Besides that, the United Nations Convention to Combat

Desertification (UNCCD) has classified these areas as having a ratio of annual precipitation to potential evapotranspiration of between 0.05 and 0.65 .

A dry-land area also includes aridity zones in which the average climatic condition is one of limited rainfall and water supplies, also known as drought. According to the United Nations Environment Programme (UNEP), there are three dry-land sub types known as dry sub-humid, semi-arid, and arid. This type of dry-land is based on the level of aridity or moisture deficit. The level of aridity is based on the ratio of the mean annual precipitation to the mean annual evaporative demand, also known as potential evapotranspiration. Dry-land areas comprise grassland, agriculture lands, forest, and urban areas. These areas provide grain and livestock, forming a habitat that supports many vegetables, fruits, and micro-organisms. Moreover, dry land has high variability in rainfall and experiences prolonged periods of drought. There are four types of drought: First is meteorological drought, which is a measure of the departure of precipitation from normal. Due to climate change differences, a drought in one location is not the same as drought in another. A second type is known as agriculture drought, a condition in which the amount of soil water is no longer sufficient to meet a crop's production needs. Third is hydrological drought, which occurs when the surface and subsurface are below normal. Finally there is socioeconomic drought, where water shortages will affect people (UNDP, 2000).

In Ethiopia, climate variability and the frequencies of extreme events have increased over recent times (CGIAR, 2013). This is greatly menacing the various agricultural sectors and natural resource base upon which the poorest Ethiopian citizens depend for their livelihoods. Improvements in crop production are dwindling, lagging very much behind the rapid rate of population growth, thus there is increasing food insecurity at both household and national level and endemic grinding poverty. Water availability has dramatically declined in Ethiopia's rivers, streams, lakes and reservoirs. Climate change, in conjunction with human activities and triggered by climate related disasters have already killed Lake Haramaya, and Adele. The predicted likely death of Lake Tana, Lake Ziway and River Awash, with the resultant loss of water resources and valuable biodiversity is too costly and painful to tolerate. There is great fear over the challenge of meeting the demands of escalating population water needs for food production including for irrigation, also domestic, municipal, and industrial and energy uses. Feed and water availability for livestock has greatly reduced and consequently livestock numbers have declined.

Dryland areas in Ethiopia are mainly rainfed and cover about three-fourths of the landmass of the country and one third of the population. They are prevalent in the eastern almost all of the Afar region, central part the Central Rift Valley, The south and southeastern including Negelle Borena, Yabelo to Moyale, Elkere, Delo, Bulbula area and many parts of south Omo, Northern drylands including almost the whole of Tigray region except some areas in western part; The Amhara region including most parts of south and north wello zone, the Oromia zone within the Amhara region and substantial parts of north and south Gonder zone They are becoming increasingly important, and are the platform for current and future development in the country. They are particularly found in the lowland areas of less or equal to 1500 masl, and in the highlands, and also in the highlands, particularly in the northern part of the country(CGIAR, 2013)..

Drylands constitute an integral part of national, regional and global agricultural production systems. Drylands are becoming a center of attention for various global reasons, including the effects of resource degradation caused by continuous increase of human and livestock populations, and aggravated by the current climate change and variability Recognizing the need to reach the poor in marginal environments, development planners and policy makers are now increasingly eyeing the hitherto less-favored dry land regions, where agricultural transformation is yet to take off Agriculture remains the dominant activity in the dryland regions. Regional Importance: currently, millions of people living in developing countries anc regions are affected by insufficient rainfall.

The main objective of this paper is to review and identify major challenges and opportunity of irrigation practices inEthiopia

\subsection{Concepts and definition related to irrigation}

Rainfall is the main source of water supply for crops, but when it becomes scarce or not evenly distributed over the entire agricultural areas it creates the gap with the actual demand for water. In this case, it is then necessary to supply water artificially, by irrigation mechanism. Irrigation define as an artificial application of water to soil for the purpose of supplying the moisture essential in the plant root-zone to prevent stress that may cause reduced yield and/or poor quality of harvest of crops (Reddy, 2010). This is an intentional action made by human to apply water for growing crops, especially during dry seasons where there is a shortage of rainfall (Reddy, 2010).

Small-scale irrigation (SSI) refers to a wide range of approaches by which soil-water can be increased and soil-water management improved. These approaches include techniques for catching, storing and using rainfall at 
or near the place where it falls (usually called rainwater harvesting); diverting flowing water by gravity; using stone/earth/brushwood or concrete structures (run-of-river or spate irrigation systems); lifting water by human or motor power (lift irrigation); conveying water by canal or pipe; and applying water to land by controlled or uncontrolled flooding (gravity), overhead sprinklers (pressurized), or drip irrigation (in the present context, usually at very low pressure (Richard Carter and Kerstin Danert,2006).

\subsection{The Importance of Agriculture Development and Irrigation for Ethiopia}

\subsubsection{Enhance Agriculture and Agriculture Productivity}

It is essential to increase agricultural productivity in order to eradicate poverty, improve the economy, and reduce degradation. Irrigation and improved agricultural water management practice is important in Ethiopia due to Population in Ethiopia is rapidly increasing (over 100,000,000 currently), land holding size particularly in highland areas is decreasing substantially ,Improved agricultural water management and irrigation can increase productivity of land, water and labor(Awlachew et.al,2008).

Figure 1. Crop yield in Ethiopia for the period of 1980-2001

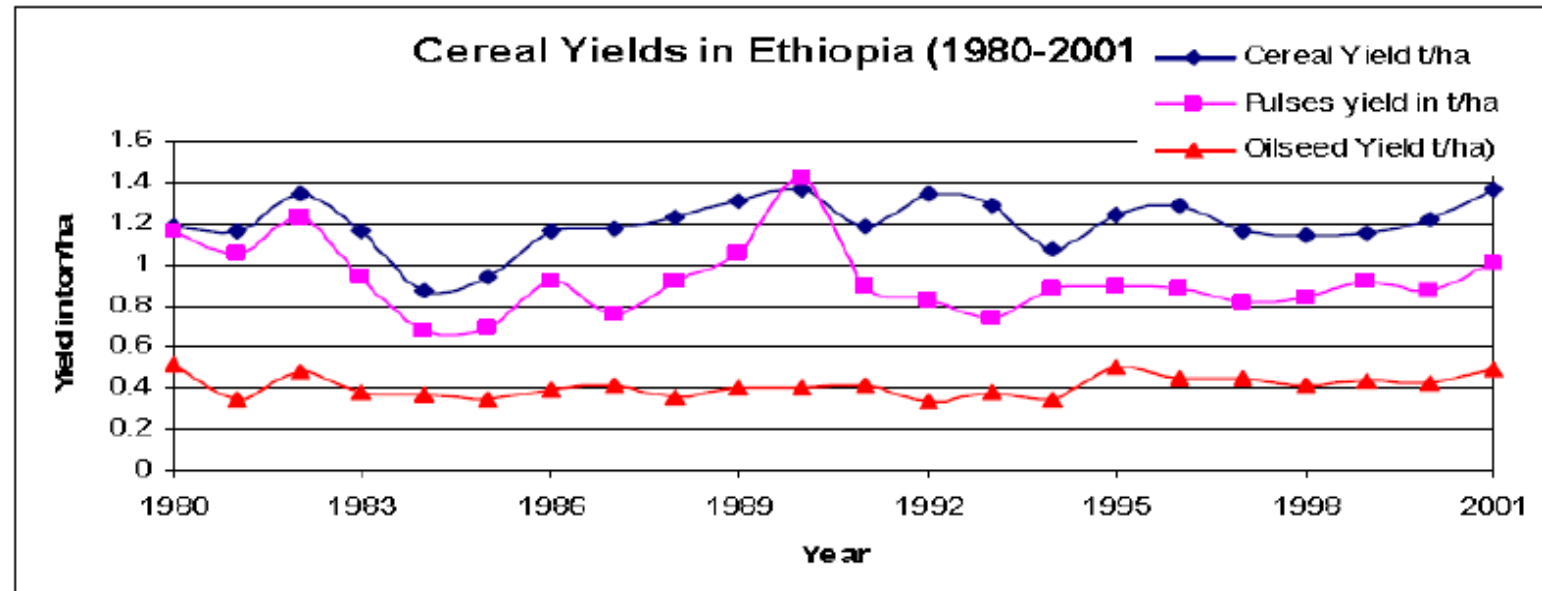

Source (Mulatet al, 2004)

\subsubsection{Poverty Reduction}

Irrigated agriculture has expanded significantly over the past five decades (Zewdie et al., 2007). World irrigated areas have almost doubled from 139Mha in the 1961 to over 273Mha in 2001 (IWMI, 2002).It seems to be a general consensus that improving agriculture and enhancing agricultural productivity will remain a key strategy for rural poverty alleviation in most developing countries (Awulachewet al., 2010). Improved access to food by the poor through their own increased production or enhanced purchasing power and economic ability to buy food would be the most effective way to move poor people out of poverty mainly in low productivity areas (Hussain and Hanjra, 2004). Moreover, Irrigation can impact poverty in three path ways.

Micro-pathway: through increasing returns to physical, human, and social capital of the poor households (productivity and distribution pathway).

Meso-pathway: through integrating the poor into factor-product and knowledge/information markets (market participation pathway).

Macro-pathway: through improving national growth rates and creating second-generation positive externalities (growth pathway (Ibid).

These pathways are very much interlinked. What happens on one particular pathway does have impacts on others. The micro-pathway operates the meso- and macro-pathways. The meso-pathway works at the local, community and regional levels and refers mainly to the secondary benefits of irrigation. The macro-pathway works at the national and transnational or global level. When we see features of irrigation investment, it requires intensive farming, labor force, use of modern inputs, more capital source, and relatively plain land and it is less risky (Shiferaw Solomon, 2011). 
Figure 2 Importance of Irrigation to Improve House Hold Welfare

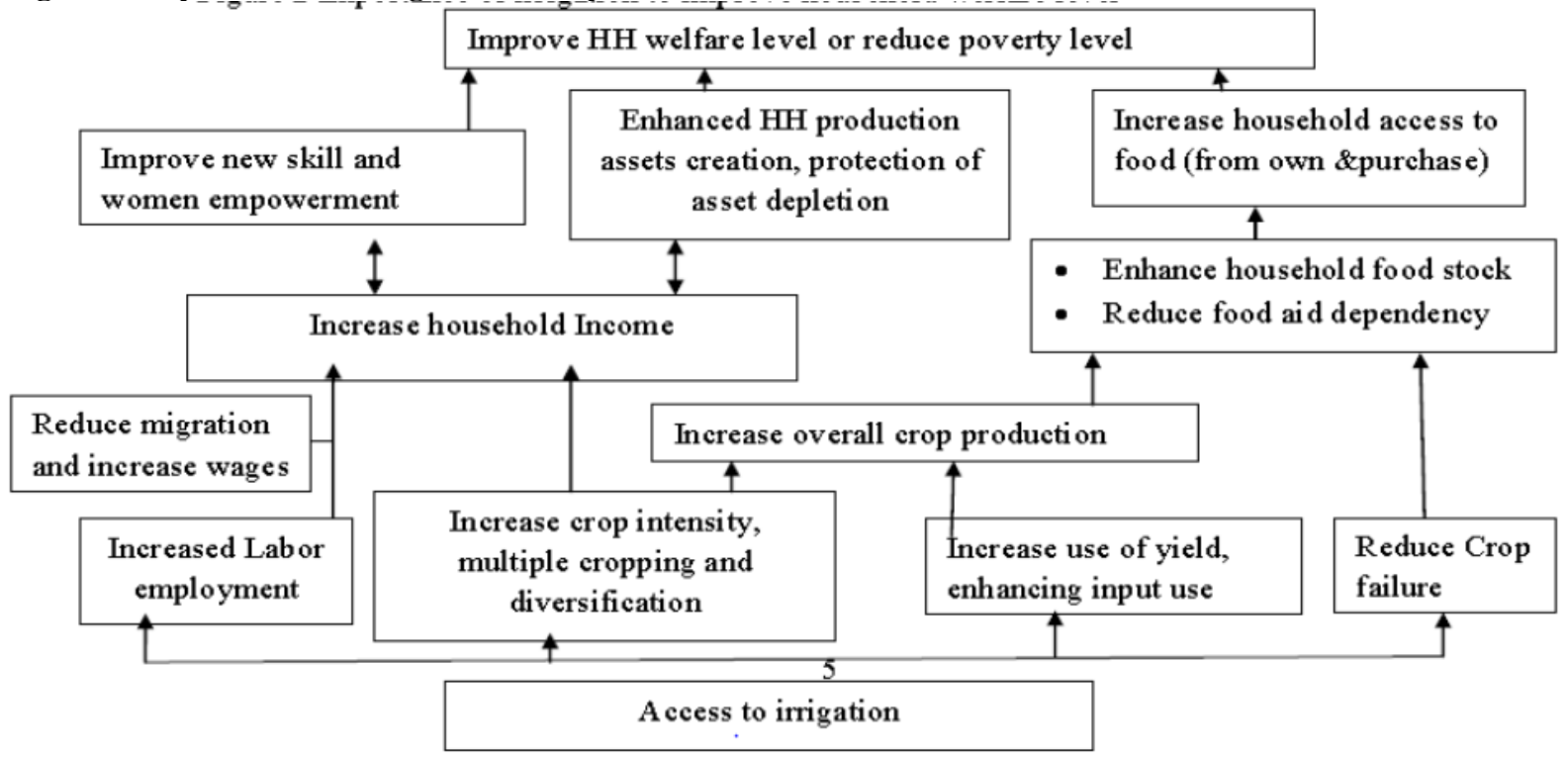

Sources: - (Shiferaw Solomon, 2011).

\subsection{Ethiopia's dry lands context and livelihoods}

Dry lands: A definition for the term 'dry lands' is hard to establish. Two of the most widely accepted definitions are those of the Food and Agriculture Organization (FAO) and the United Nations Convention to Combat Desertification (UNCCD). FAO has defined dry lands as those areas with a length of growing period (LGP) between 1 and 179 days (FAO, 2000); this includes regions classified climatically as arid, semi-arid and dry subhumid. On the other hand, the UNCCD defines dry lands based on aridity index, which is a ratio of annual precipitation to potential evapotranspiration (P/PET). According to this ratio, dry lands are defined as areas with an aridity index in the range of 0.05 to 0.65 (UNCCD, 2000). According to these definitions, $40 \%$ of the world's total land area is believed to be located in dry lands.

Drought prone areas: According to FAO (2004), a drought is defined as: a departure from the average or normal rainfall conditions; sufficiently prolonged (1-2 years) as to affect the hydrological balance; and adversely affecting ecosystem functioning and the resident populations. Drought prone areas are therefore areas characterized by variable amounts and intensity of rainfall. Dry lands are impacted by high variability in rainfall, and also by the occurrence of prolonged periods of drought. According to the National Oceanic and Atmospheric Administration (NOAA) of the United States there are four different types of drought. Meteorological drought is a measure of the departure of precipitation from normal. Due to climatic differences, a drought in one location may not be a drought in another location. Agricultural drought refers to situations where the amount of soil water is no longer sufficient to meet the needs of a particular crop. Hydrological drought occurs when surface and subsurface water supplies are below normal. Socio economic drought describes the situation that occurs when physical water shortages begin to affect people.

Dry land agro-ecology: Agro-ecology is defined as farming that centers on food production that makes the best use of nature's goods and services while not damaging these resources. Dry land agro-ecology refers to agricultural practices in dryads. The agro-ecologies of Ethiopia's production systems are wide-ranging and diverse, and found in the arid, semi-arid and dry sub humid areas. They are prevalent mainly in the north, east, central rift valley areas, south and southeastern parts of the country within very wide and diversified agricultural environments. In the Ethiopian context, dry lands cover about $75 \%$ of the total land area of the country. They are home to a rapidly growing population that stands at about one third of the total Ethiopian population estimated at 35 million (UNCCD, 2000).

The dry lands are also home to large populations of livestock. It is evident that the dry lands experience moisture stress during most days of the year, having only 45-120 days of growing season per year (Kidane et al, 2010). They are characterized by low and erratic rainfall with uneven distribution and frequent drought. Their altitude ranges from -124 to over 2500 m.a.s.l while rainfall ranges from 200 to $800 \mathrm{~mm}$ annually. The dry lands contain wide-ranging and diversified agro ecologies and are endowed with high species diversity, both of animal and plant origin, presenting great opportunities for economic development. Vegetation is scattered, often degraded, and very sparse, leaving areas of the soil uncovered. In many dryad areas, except at the valley bottoms, the soils have low organic matter content, are highly eroded and poor in fertility 


\subsection{Crop Production in the dryland areas of Ethiopia}

In the dryland areas of Ethiopia, crop yields are principally limited by the low and highly variable rainfall, both between and within seasons. This is now being aggravated by the ongoing climate change. The length of rainfall period is being reduced, as it is generally starting later and finishing earlier. Production is also limited to the progressive decline in soil fertility, as the farming practices do not adequately restore nutrients. This loss of soil fertility is also linked to a decline in soil organic matter content, resulting in limited soil water holding capacity, poor water infiltration rates, thus limiting the availability of both water and nutrients to the crop plants.

There is also evidence which indicate the temperatures are increasing, leading to higher rates of evapotranspiration and heat stress to crops, further limiting their yield potential. Thus the production in these areas is declining consequently food in security, poverty and overall poor livelihood conditions prevail in these areas. In order to address these problems drought resistant, early maturing and heat tolerant crop species and varieties have been developed by the research systems in Ethiopia (CSA, 2008). These crop technologies include cereals which are the major food crops, also grain legumes, oil.

Cereals: The major cereal crops in the dryland areas are sorghum, maize, tef and millet. These are the major food crops for humans diet and also provide feed for animals, The improved varieties developed by the NARS in Ethiopia in collaboration with CGIAR centers such as CIMMYT, ICRISAT, ICARDA and others are describes below. The crop varieties, the adaptation areas and the growing conditions are detailed below.Sorghum is a very important crop in the country, with high genetic potential grain yield of 7.0 to $9.0 \mathrm{t} / \mathrm{ha}$, while the national productivity is low about $1.7 \mathrm{t} / \mathrm{ha}$ (CSA, 2008). Productivity could be doubled using improved varieties (see Table 2)

Table 1 Sorghum varieties recommended for dryland areas of Ethiopia

\begin{tabular}{|c|c|c|}
\hline Sorghum variety & Main Description & Best adaptation areas \\
\hline Gambela-1107 & $\begin{array}{l}\text { Yield potential ranges from } 2.5-3 \text { t/ha. } \\
\text { Utilization - good for injera making. It } \\
\text { is relatively resistant to most pest and } \\
\text { diseases of sorghum. }\end{array}$ & $\begin{array}{l}\text { Well adapted to low elevations } \\
(<1600 \mathrm{ml}) \text { with more than } 600 \mathrm{~mm} \\
\text { of rainfall annually in semi-arid } \\
\text { areas including Gambella, Yabello, } \\
\text { Jijga Kobo, Shewa robit. }\end{array}$ \\
\hline $76-\mathrm{T} 1-23$ & $\begin{array}{l}\text { IA very early maturing variety (60-70 } \\
\text { days to anthesis) which fits well to the } \\
\text { dry semi-arid areas. Utilization - good } \\
\text { quality for making injera with high } \\
\text { preference of customers. }\end{array}$ & $\begin{array}{l}\text { North Wello in Kobbo Alamata } \\
\text { area, Cheffa area, north Shewa } \\
\text { and Meiso area. }\end{array}$ \\
\hline Melko-1 & $\begin{array}{l}\text { An early maturing, drought and heat } \\
\text { resistant variety. Utilization - white seed } \\
\text { with good for injera making quality. Also } \\
\text { high biomass production therefore is } \\
\text { good for animal feed. }\end{array}$ & $\begin{array}{l}\text { Dry semi-arid areas with short } \\
\text { growing season. It is released for } \\
\text { north Shewa, Kobbo and other } \\
\text { similar areas. }\end{array}$ \\
\hline Gubiye and Abshir & $\begin{array}{l}\text { Similar in characteristics to Melko- } 1 \\
\text { in terms maturity, drought and heat } \\
\text { resistance and utilization. Additional } \\
\text { attribute is its resistance to the parasitic } \\
\text { weed called striga. }\end{array}$ & $\begin{array}{l}\text { north Shewa, Kobbo and Meiso } \\
\text { areas and well adopted by farmers } \\
\text { and other dry-semi-arid areas. }\end{array}$ \\
\hline Macia & $\begin{array}{l}\text { High yield potential of about } 3 \text { tha. This } \\
\text { variety stays green, has broad leaves with } \\
\text { juicy thick stem and good quality crop } \\
\text { residue used for livestock fodder. }\end{array}$ & $\begin{array}{l}\text { It is widely adapted in semi-arid } \\
\text { areas and short growing areas } \\
\text { with elevation of less than } 1600 \mathrm{~m} \text {. }\end{array}$ \\
\hline Seredo & $\begin{array}{l}\text { Bird resistant, drought tolerant, with } \\
\text { high tannin content and very good for } \\
\text { arekie making (local drink). }\end{array}$ & $\begin{array}{l}\text { All dry semiarid of the lowlands } \\
\text { particularly in the rift valley } \\
\text { areas where problem is a major } \\
\text { constraint for sorghum production. }\end{array}$ \\
\hline Teshale & $\begin{array}{l}\text { Early, days to maturity } 100-120 \text {, yield } \\
3.0-4.5 \text { t/ha, high biomass production } \\
\text { used for feed. }\end{array}$ & $\begin{array}{l}\text { Dry lowland with altitude less than } \\
1600 \mathrm{~m} \text {, lowlands of north wello } \\
\text { and north Shewa. }\end{array}$ \\
\hline
\end{tabular}


The improved varieties identified by NARS are early maturing and well adapted to the dryland areas of Ethiopia. Most of the varieties also combine high yielding capacity with earliness, also disease and pest resistance. Some of the varieties are also resistant to striga, the parasitic weed which is a threat to sorghum production in many African and Asian countries. The sorghum varieties for the lowland dryland areas altitude up to 1600 above sea level.are the last decade production is increased by 162 percent, due to increased area coverage ( 69 percent) and increased productivity by about 58 percent.

However improved seed and fertilizer have not been changed. In 2007 from the total areas covered by sorghum 0.14 percent used improved seed and 19 percent used fertilizer (CSA 2007 percent).This indicates that although there are improved varieties with high genetic potential developed, due lack of improved seed and limited availability of other inputs such as fertilizer the farming communities could not benefit from the technology. Lack of improved and other inputs is therefore limiting production and productivity leading to food insecurity. This needs policy attention.

Tef Production is the major cereal crop grown in Ethiopia and its production exceeds that of most other cereals. Each year, the area of production allocated to tef is estimated to be 2.5 million hectares and the production could reach about 0.9 million tons of grain or about one quarter of the Ethiopia's total cereal production (CSA 2008). Tef is grown either as a staple or as standby. As a staple, it is planted as other cereals, normally sown late and harvested during the dry season. During dry seasons or late onset of rains, the production area of tef increases. As a standby, the farmers wait until the main crops (maize and sorghum) show signs of failing. Then they sow a fast maturing tef variety as a backup for sustenance in the case of disaster. It is thus an important crop for drought prone areas where climate variability and change is major threat. The crop varieties developed for adaptation for these problems are indicated in Table 2 below.

Table 2 Improved tef varieties for drylands

\begin{tabular}{|c|c|c|}
\hline Tef variety & Main description & Best adaptation areas \\
\hline Sidama DZ-Cr-385 & $\begin{array}{l}\text { Grain yield potential is } 1.2-1.8 \mathrm{t} / \mathrm{ha} \\
\text { with a straw yield of } 6.5-8.0 \text {, seed } \\
\text { color is white. Provide high biomass } \\
\text { for animal feed and other purposes. }\end{array}$ & $\begin{array}{l}\text { Altitude } 1350-1700 \mathrm{~m} \text { with rainfall } \\
\text { of } 300-600 \text { suitable dryland } \\
\text { semiarid areas. }\end{array}$ \\
\hline $\begin{array}{l}\text { DZ-Cr387 Ril } 127 \\
\text { (Gemechis) }\end{array}$ & $\begin{array}{l}\text { The yield potential in research } \\
\text { center is } 1.5-2.2 \text { t/ha as compared } \\
\text { to } 1.2-1.4 \text { t/ha in farmers yield. It is } \\
\text { very white colored seed with good } \\
\text { quality seed and high market value. }\end{array}$ & $\begin{array}{l}\text { Altitude ranging from } 1450-1700 \mathrm{~m} \\
\text { a s I and rainfall } 600-1950 \mathrm{~mm} \text {. It is } \\
\text { adapted in almost all semi-arid areas } \\
\text { falling within this range. }\end{array}$ \\
\hline DZ-Cr-37 (Tsedey) & $\begin{array}{l}\text { Grain yield potential is } 1.4-2.2 \mathrm{t} / \mathrm{ha} \\
\text { with a straw yield of } 8.2-9.0 \text {. } \\
\text { It is white colored seed with good } \\
\text { quality seed and high market value. }\end{array}$ & $\begin{array}{l}\text { This include areas with altitude } \\
\text { ranging from }<1600 \text { to } 2000 \mathrm{~m} \\
\text { a s I and rainfall } 300 \text { to } 700 \mathrm{~mm} \text {. } \\
\text { It is adapted in almost all semi-arid } \\
\text { areas falling within this range. }\end{array}$ \\
\hline DZ-01-96 (magna) & $\begin{array}{l}\text { Grain yield potential is } 1.4-2.8 \mathrm{t} / \mathrm{ha} \\
\text { with a straw yield of } 8.2-9.0 \text {, seed } \\
\text { color is very white }\end{array}$ & $\begin{array}{l}\text { Altitude } 1800-2400 \mathrm{~m} \text { with rainfall } \\
\text { of } 300-700 \mathrm{~mm} \text {, high quality tef }\end{array}$ \\
\hline HO-Cr-136 (Amarech) & $\begin{array}{l}\text { The yield potential in research is } \\
1.3-1.8 \text { as compared } 1.2-1.4 \text { tha in } \\
\text { farmers yield. It is brown colored } \\
\text { seed with good quality seed and } \\
\text { high market value. }\end{array}$ & $\begin{array}{l}\text { Altitude ranging from } 1600-1700 \mathrm{~m} \\
\text { a s I and rainfall } 300-800 \mathrm{~mm} \text {. } \\
\text { It is adapted in almost all semi-arid } \\
\text { areas falling within this range }\end{array}$ \\
\hline DZ-01-1681 (key tena) & $\begin{array}{l}\text { Grain yield potential is } 1.6-2.5 \text { t/ha } \\
\text { with a straw yield of } 8.4-9.3 \text {, seed } \\
\text { color is brown }\end{array}$ & $\begin{array}{l}\text { Altitude } 1600-2000 \mathrm{~m} \text { with rainfall } \\
\text { of } 300-500 \mathrm{~mm} \text {. }\end{array}$ \\
\hline DZ-01-354 (Enatit) & $\begin{array}{l}\text { Grain yield potential is } 1.7-2.8 \mathrm{t} / \mathrm{ha} \\
\text { with a straw yield of } 8.5-13.0 \text {, seed } \\
\text { color is pale white }\end{array}$ & $\begin{array}{l}\text { Altitude } 1600-2400 \mathrm{~m} \text { with rainfall } \\
\text { of } 300-700 \mathrm{~mm} \text {. }\end{array}$ \\
\hline DZ-01-99 & $\begin{array}{l}\text { Grain yield potential is } 1.7-2.2 \mathrm{t} / \mathrm{ha} \\
\text { with a straw yield of } 8.5-13.0 \text {, seed } \\
\text { color is brown }\end{array}$ & $\begin{array}{l}\text { Altitude } 1400-2400 \mathrm{~m} \text { with rainfall } \\
\text { of } 300-700 \mathrm{~mm} \text {. }\end{array}$ \\
\hline $\mathrm{DZ}-\mathrm{Cr}-44$ & $\begin{array}{l}\text { Grain yield potential is } 1.7-2.8 \mathrm{t} / \mathrm{ha} \\
\text { with a straw yield of } 12.5-14.0 \text {, } \\
\text { seed color is white }\end{array}$ & $\begin{array}{l}\text { Altitude } 1800-2400 \mathrm{~m} \text { with rainfall } \\
\text { of } 300-700 \mathrm{~mm} .\end{array}$ \\
\hline
\end{tabular}

Source: Ethiopian Institute of Agricultural Research, unpublished data, workshop 2010 


\section{Opportunities of irrigated crop production in dry land}

Despite the fact that small scale irrigation in Ethiopia has been in different the opportunity are numerous.

\subsection{Natural Resource}

Ethiopia's plentiful water resources, large tracts of available land, good soils, and suitable climatic conditions for the production of many crops present significant opportunities for intensifying its irrigation sector. The country's resources make it ideal for the commercial farming of key staple crops such as wheat, sugar, and maize, which would also help create more jobs (Diogo Machado Mendes and Lisa Paglietti, 2015)

\subsubsection{Surface water potential}

Ethiopia is endowed with water resources, which could be easily tapped and used for irrigation. The total surface of the 18 natural and artificial lakes in Ethiopia is about 7,500 km2. Seven out of the eight major natural lakes are found in the drylands as shown in the following map (EPA and MEDAC 1997). The major rivers in the drylands are given as an example the water resource

Prevalent in the dryland production system (Kidane Georgis 2005). The estimated irrigation potential is about 3,000,000 ha, but so far only $5 \%$ has been utilized and most of the important rivers, which could be used for irrigation, are located in the drylands. This includes the Awash, Wabi-shebele, Genale, Dawa, Bilate, Segen, Omo, and Tekeze-Angereb-Goang. There are water sources with high potential for consumption, irrigation and as sources of energy in the form of rivers (Awash, Wabi Shebele, Genale, Dawa, Baro, Omo, etc) and lakes in the Rift valley (Awassa, Shalla, Abijata, Chamo, Rudolf etc) as well as potential ground water resources. So far over $70 \%$ of the areas developed to irrigation are entirely in the Awash River basin and the rest is less exploited.

There are high potential water resources particularly in the pastoral areas. For example the country wide Water Resources Master Plan (1998) indicates that Genale- Dawa and Wabi-Shebele can be used to develop 423,300 and 204,000 gross irrigable hectares of land with mean annual volume of 5.88x109m3 and $3.16 \times 109 \mathrm{~m} 3$. The groundwater potential in the pastoral areas is also high. For example, in most places of Somali, underground water is obtained at a less than 10 meters depth in most areas. However, the ground water resource has not been fully studied and this should receive attention for irrigated production of crops, vegetables, fruits and forcge.In the country according the water resource data the annual surface water is 122.12 billon $\mathrm{m}^{3}$, ground water $2.6-13.5$ billion $^{\mathrm{m}}$, irrigation $250 \mathrm{k} / 3.5$ ha are reported

Table 3 Irrigation potential in river basin Ethiopia

\begin{tabular}{|c|c|c|c|c|c|}
\hline \multirow[t]{2}{*}{ Basin } & \multirow[t]{2}{*}{$\begin{array}{l}\text { Catchment } \\
\text { Area }\left(\mathrm{km}^{2}\right)\end{array}$} & \multicolumn{4}{|c|}{$\begin{array}{l}\text { Irrigation potentials (ha) } \\
\text { (Respective recent master plan studies) }\end{array}$} \\
\hline & & $\begin{array}{l}\text { Small } \\
\text { scale }\end{array}$ & $\begin{array}{l}\text { Medium } \\
\text { scale }\end{array}$ & $\begin{array}{l}\text { Large } \\
\text { scale }\end{array}$ & Total \\
\hline Abay & $198,890.7$ & 45,856 & 130,395 & 639,330 & 815,581 \\
\hline Tekeze & $83,475.94$ & $\mathrm{~N} / \mathrm{A}$ & $\mathrm{N} / \mathrm{A}$ & 83,368 & 83,368 \\
\hline Baro-Akobo & $76,203.12$ & $\mathrm{~N} / \mathrm{A}$ & $\mathrm{N} / \mathrm{A}$ & $1,019,523$ & $1,019,523$ \\
\hline Omo-Ghibe & 79,000 & $\mathrm{~N} / \mathrm{A}$ & 10,028 & 57,900 & 67,928 \\
\hline Rift Valley & 52,739 & $\mathrm{~N} / \mathrm{A}$ & 4,000 & 45,700 & 139,300 \\
\hline Awash & $110,439.3$ & 30,556 & 24,500 & 79,065 & 134,121 \\
\hline Genale-Dawa & 172,133 & 1,805 & 28,415 & $1,044,500$ & $1,074,720$ \\
\hline Wabi-Shebele & $202,219.5$ & 10,755 & 55,950 & 171,200 & 237,905 \\
\hline Danakil & $63,852.97$ & 2,309 & 45,656 & 110,811 & 158,776 \\
\hline Ogaden & 77,121 & & & & - \\
\hline Ayisha & 2,000 & & & & - \\
\hline Total & $1,118,074.53$ & & & & $3,731,222$ \\
\hline
\end{tabular}

Source: - Major rivers in the drylands of Ethiopia (Georgis 2005) 


\subsubsection{Ground water potential}

As noted above, groundwater in Ethiopia can be used for irrigation in multiple ways, such as deep and shallow wells from underground aquifers. Compared with other sources of irrigation, groundwater as a resource for agricultural development offers a number of advantages, including:

- Reliability of the water source, since it has a naturally renewable capacity if water is not extracted above certain thresholds

- On-demand water supply through natural water storage

- Domestic water source, with no trans-boundary considerations

- Availability in many places, e.g., in highlands, steep terrains, inland valleys, and plain areas

- Relative constancy of supply, which can help to buffer the high variability of surface water resources. there are major opportunities for the development and protection of groundwater, including: (i) exploiting shallow groundwater; (ii) enhancing water recharge in aquifers, including forestation in hilly areas, infiltration galleries, and subsurface dams to increase the available water in the sub-surface; and (iii) using a watershed-based approach to enhance soil and water conservation and increase the groundwater level in the valley bottoms for easy access to groundwater. In this study, estimates suggest that groundwater irrigation potential is $1.1 \mathrm{Mha}^{8}$. Irrigable potential by zone is summarized in the following table.

Table 4Groundwater potential in the 3 Ethiopian zones

\begin{tabular}{lll}
\hline Zone and ground potential & Available water (BM3) & Irrigation potential (ha) \\
\hline Zone 1 high potential & 1.06 & 211,386 \\
\hline Zone 1 medium potential & 0.83 & 137,636 \\
\hline Zone 1 low potential & 0.23 & 32,317 \\
\hline Zone 2 high potential & 0.63 & 126,806 \\
\hline Zone 2 medium potential & 0.49 & 81,542 \\
\hline Zone 2 low potential & 0.23 & 32,317 \\
\hline Zone 3 high potential & 1.56 & 311,808 \\
\hline Zone 3 medium potential & 0.85 & 141,989 \\
\hline Zone 3 low potential & 0.63 & 90,081 \\
\hline Total & 6.5 & $1,165,881$
\end{tabular}

Source: - (Awulachew and Mekonin, 2011)

\subsubsection{Rainwater harvesting $(\mathrm{RWH})$ potential}

Currently rainwater use in Ethiopian agriculture involves both unmanaged and managed rainwater use in rain-fed agriculture. The former is the major source of agricultural water in crop, livestock, agro-forestry and related sectors, e.g., rainwater directly irrigating fields and pastures. In the latter, farmers use rainwater to maximize availability of soil moisture at a household level, with rainwater harvesting and shallow wells and through spate (flood) irrigation. Rainwater management can also be applied to water-logged areas of farm land.In terms of increasing irrigation potential incrementally to the formal irrigation component, through RWH and better water management, the study estimates that RWH can provide an additional 0.5 Mha in irrigation ${ }^{9}$. The study assumes that such measures are most important in zone 2 due to its low and highly variable rainfall, leading to a need for supplementary irrigation. In zone 1, capturing RWH potential could be through spate and shallow hand-dug wells, while for zone 3, the irrigation potential from RWH is minimal due to low rainfall (Kidane Georgis 2005).

\section{Major Challenges of irrigated crop production in dry land}

It is important to give a brief account of the pressing biophysical, socioeconomic institutional and policy problems hindering the development dryland areas of Ethiopia. As a result, this section gives brief account on the major problems of developing of dryland areas.

\subsection{Water Stress and Recurrent Drought}

The key problems in the drylands are water stress and associated drought incidence. Water stress is a universal 
problem and common denominator to all drylands in Ethiopia and drylands of the world. It means that in dryland agriculture, water is central production factor affecting sustainability. In Ethiopia, the strategy in dryland agriculture is based on conducting dryland research with water as a nucleus in well-defined watershed units (Kidane Georgis, 2004). Climate change is also a consistent threat in the drylands in Ethiopia. Long-term change in temperature and rainfall patterns is having serious impact on biodiversity of the drylands of Ethiopia. Consistent shift in the rain pattern and recurrent drought are becoming more prevalent, while rainfall patterns are expected to become more erratic and agro-ecosystems vulnerable to food and feed shortage.

This is likely to become more difficult in the future, as in GCM scenarios for east Africa pointing out an overall reduction in soil moisture availability. The major causes of water stress and drought are low erratic and highly variable rainfall, high evapotranspiration rates, shallow infertile soils with poor water holding capacity. So drought is very prevalent in the dry areas. However, the problem with drought is that it is a silent killer, and is the natural catastrophe that is too easily forgotten. Experience shows that awareness of the implications of desertification and drought must be expanded and that policy orientation must be backed by robust monitoring systems and related finding

\subsection{Climate Change and Variability}

Climate change is a major threat to the livelihood of the majority of the population pariicularely in the drylands. Climate change is leading to irreparable ecological degradation and has reduced agricultural productivity, with serious consequences in food production and food security. Besides, East Africa with the predominance of rainfed agriculture is severely affected by climate change. The Region faces a particularly daunting situation as agriculture is the mainstay of the economies of many countries, accounting for over $30 \%$ of the total GDP, over $50 \%$ of export earnings, and with over $90 \%$ of rural liv elihoods dependent on rainfed agriculture and agriculture-based rural activities (Kidane Georgis 2005).

\subsection{Land Degradation}

Land degradation in most agricultural lands in Ethiopia, particularly in the drylands is taking place at alarming rate. The major causes are the ever increasing human and livestock population and the associated demand for the basic natural resources such land, water, forest and other agro-biodiversity resource and their products (Georgis, 2005). Pressure in the drylands is expected to increase in the next decade, as the growing population both human and livestock increase.Land degradation and sever erosionshave led to the loss of top soil in many dry areas.Currently,extensive drylands of the country, particularly the arid regions of Afar and Somali, are under continuous threat of desertification, and substantial areas in t ne highlands of northern part of the country's croplands are abandoned annually because cropping can no longer be supported on the highly degraded areas.

Even in good rainfalls, farmers cannot produce enough to sustain them selves since the soil depth has been reduced and organic matter and nutrients have already been depleted Human and livestock population increase is rendering the most common conversion lands unsuitable for cultivation to croplands; sloppy, highly degraded areas usuallynot suitable for crop production are being cultivated. Poor soil and water management have also led to degradations in many drylands of Ethiopia. In the drylands of agro-pastoral and pastoral areas in particular, there is a huge number of livestock and wildlife. Hence, their impact on dryland biodiversity through tripling and removal of biomass, alteration of species composition through selective consumption and changed inter-plant composition, and redistribution of nutrients through dropping of urine and faces leads to land degradation. Changes in grazing intensity and selectivity will inevitably change the dryland biodiversity.

\subsection{Pests and Disease Infestation}

Apart from drought, up to $40 \%$ annual losses are estimated to be caused by a large Number of pests and diseases which damage the crops and livestock in the semi-arid regions. Weed infestation is also major problem in the drylands.Weeds, if not properly controlled at the right time; compete for the scarce resources of nutrients and soil water in the dry areas, aggravating low soil fertility and water stress. Yield loss associated with weed infestation could generally reach $30 \%$ or more (sometimes as high as $100 \%$ in case of parasitic weeds such as striga in sorghum) due to weed infestation in the lowland areas, especially in sorghum production. Several exotic plants have been purposely or accidentally introduced in Ethiopia and other parts of eastern Africa.

Some of these plants have become serious intensive wee-ds in agriculture, pasture land and water ways. Two of these most important invasive species in Ethiopia are Prosopis species (e.g. Prosopis juliflora) andParthenium hysterophorus.They are important in several drylands in crop/livestock, pas:oral/agropastoralproduction areas (Georgis, 2004). They are severely threatening the biodiversity, plant composition and economic functions. These invasive weeds are growing out of control in agricultural lands, rangelands, national parxs, roadsides and green spaces with great economic and ecological consequences in the dry areas. Several indigenous Acacia species are also invading rangeland and causing a serious threat to the rangeland resources, livestock production and native biodiversity in the pastoral areas 


\section{Summary and conclusion}

Though the Green Revolution transformed many regions in the developing world, it did not reach the poor in the drylands. Poverty, population explosion, water scarcity, land degradation,

Migration and other health constraints persist. The low productivity of dryland agriculture,

Coupled with a changing global environment, further threatens to marginalize agriculture and

Livelihoods in the drylands of Asia and sub- Saharan Africa. These areas require approaches

That differs from the Green Revolution strategy. A broad vision for dryland agriculture would involve reducing poverty, hunger and malnutrition, and ensuring sustainable livelihoods for everyone. This vision can be achieved through a multi-pronged strategy to accelerate the pace of development of dryland agriculture, which requires synergy among technologies, marketing systems, input supplies, credit, policies and institutions.

These dry-land developing countries have faced food shortages due to high variability in both rainfall amounts and intensity problems. These have faced prolonged periods of drought. A drought is defined as a departure from the average or normal conditions, sufficiently prolonged as to affect the hydrological balance and adversely affect ecosystem functioning and resident

Populations. In addition, these also faced water scarcity problems, which caused insufficiency in land irrigation.

More challenging is the increase of agricultural productivity in existing schemes. There is much less attention by the water leading experts to that issue and a low awareness of the magnitude of the investments required to achieve the goals set up by the above models. The lack of consensus on the causes of the poor performance of canal systems may have contributed to the slow progress in addressing the main challenge of irrigation: the performance of surface irrigation systems

It can be concluded that there is a lot resource potential in the drylands and pastoral/agro-pastoral production system, which is untapped, but could be used for the development of sustainable agriculture, if used properly. This include base natural resource such huge amount of water resources, fertile soils, forest resources, energy and minerals, key watershed and wetlands and important biological diversity.Closer studies of long-term landscape changes, of rangeland ecology, of community natural resource management regimes, and of agricultural intensification processes reveal many cases where the resource management practices adopted by the people living in an area have unjustly been seen as degrading the land. Thus, overgrazing has probably been exaggerated as a problem, especially in the driest areas. Much is still unknown, however, about how dryland ecosystems are affected by different resource management practices

Irrigated Agriculture no doubt is a profitable and sustainable venture for farmers. The result of this reviews aviso (showed) that improper or inefficient irrigation water delivery performance, unavailability of irrigation scheme performance dissatisfaction of irrigation user, illiteracy (absent of awareness ) about how and when irrigation are to be irrigated and misconception about irrigation crop water requirement, post harvesting and marketing issue, inputaccess, irrigation canal damaging, and schemedelivery failed were major issue that hindering or challenging small scale development in Ethiopia

\section{Future irrigation programs dryland in Ethiopia}

The Ethiopian Irrigation Development Plan (IDP) emphasizes the development of small-scale irrigation advancements so as to assure Ethiopian livelihoods especially in the dryland rural areas. However, the contribution of irrigation to the national economy as compared to its potentials is non-negligible. This indicates more investments on the area have paramount importance for the development of the country. Generally, the government and peoples of Ethiopia believes that irrigation can play a significant role for food security enhancement and economic growth. Therefore, intensive investments should be operated in the sector by governmental, non-governmental and privates investors

\section{REFERENCES}

AbebawAbiyu .MesfinTebeje, 2016. Challenges and Opportunities of Small-Scale Irrigation Utilization in Rift Valley Basin, HumboWoreda, Ethiopia, Journal of Economics and Sustainable Development

Awulachew, S. and Mekonin, A. 2011. Performance of Irrigation: An Assessment at Different Scales in Ethiopia. Journal of Experimental Agriculture. 47 (1): pp57-69

Awulachew, S., Merrey, D., Van Koopen, B. and Kamara, A. 2010. Roles, Constraints and Opportunities of Small-Scale Irrigation and Water Harvesting in Ethiopian Agricultural Development

Bajwa, M.I., M.S. Zia and P.A. Naim. 1991. Research findings in arid lands of Pakistan: A summary. Pakistan Agric. Res. Council, Islamabad, Pakistan

CGIAR. (2013). New Research Approaches to improve drylands agriculture to deliver a more prosperous future. Ethiopia

Diogo Machado Mendes and Lisa Paglietti, 2015.Ethiopia Irrigation market brief, Food and Agriculture organization Of the United Nations Rome, 2015. 
EPA and MEDAC. 1997. The Resource Base and its Utilization and Planning for sustainability. In the Conservation Strategy of Ethiopia, Volume 1, ppl38.

FAO 2010. Preliminary Review of the Impact of Irrigation on Poverty with Special Emphasison Asia. Land and Water Development Division, Water Resources, Development and Management Service Rome, Italy

Hamdtulu, 2014: The Effects Of Small Scale Irrigation On Ruralhouseholds' Income: The Case Of Adami Tulu Jido Kombolcha District, Oromia National Regional State.

Hussain, Intizar and Munir A. Hanjra, 2004. Irrigation and poverty alleviation: Review of the empirical evidence. John wiley\& sons, ltd. irrig. And drain. 53: 1-15. International Water Management Institute, Colombo, Sri lanka

Kidcine Georgis. 2005. The role and contribution of dryland biodiversity in Ethiopia, Paper presented at the regional workshop of biodiversity held at Dar Es Salaam University during 13-17, 2005

Kidane Georgis, John H Sanders, Della Macmillan and ELuid O. Omolo. Technologies.

2004. Technologies, Policy Exchanges and market Development to increase crop production in the Semi-arid Ethiopia. Igad/lntSOMIL/USAYD-REDSO.

Mulat Demeke, FantuGuta and Tadelle Fered. 2004 Agricultural Development In Ethiopia: Are There Alternatives To Food Aid? Department of economics, Addis Ababa University.

Rashid, A., and F. Hussain, 1994. Fertilizer efficiency in rainfed agriculture. p. 39-397. In N. Ahmad et al. (ed.) Efficient use of plant nutrients. Proc., 4th Natl. Congress of Soil Sci., Islamabad. 2426 May 1992. Soil Sci. Soc. Pakistan, Islamabad, Pakistan.

Rashid, A., E. Rafique, S. Muhammed, and N. Bughio. 2002a. Boron deficiency in rainfed alkaline soils of Pakistan: Incidence and genotypic variation in rapeseed-mustard. p. 363-370. In H.E. Goldbach et al. (ed.) Boron in plant and animal nutrition. Kluwer Academic/Plenum Publ., New York.

Reddy RN 2010. Irrigation Engineering, Gene-Tech Books,New Delhi -110 002

Richard Carter and Kerstin Danert, 2006. FARM-Africa Ethiopia: Planning for Small- Scale Irrigation Intervention, Working Papers series 4

Kerr, J. (2002). 'Watershed development, environmental services and poverty alleviation in India', World Development 30: 1387-1400

Keller, A., and D. Seckler. 2004. Limits to Increasing the Productivity of Water in Crop Production. Arlington, Va.: Winrock Water.

Moriarty, P., J.A. Butterworth, and B. van Koppen, eds. 2004. Beyond Domestic: Case Studies on Poverty and Productive Uses of Water at the Household Level. IRC Technical Paper Series 41. Delft, Netherlands: IRC International Water and Sanitation Centre

Polak, P., and R. Yoder. 2006. "Creating Wealth from Groundwater for Dollar-a-Day Farmers: Where the Silent Revolution and the Four Revolutions to End Rural Poverty Meet." Hydrogeology Journal 14(3): 424-32.

Postel, S., P. Polak, F. Gonazales, and J. Keller. 2001. "Drip Irrigation for Small Farmers: A New Initiative to Alleviate Hunger and Poverty." Water International 26 (1): 3-13.

Sayre, K.D., S. Rajaram, and R.A. Fischer. 1997. "Yield Potential Progress in Short Bread Wheats in Northwest Mexico."

Crop Science 37 (1): 36-42.

SAMUHA. (2003). 'LEAD report SAMUHA', unpublished project report, IWMI: Hyderabad

Seckler, D. 1996. The New Era of Water Resources Management: From 'Dry' to 'Wet' Water Savings. Research Report 1. Colombo: International Irrigation Management Institute.

Shifrawu Solomon 2011.The Impact of Small-Scale Irrigation on Household Food Security: The Case of Filtino and Godino Irrigation Schemes in Ethiopia.

Tanner, C.B., and T.R. Sinclair. 1983. "Efficient Water Use in Crop Production: Research or Re-search?" In H.M. Taylor,W.A. Jordan, and T.R. Sinclair, eds., Limitations to Efficient Water Use in Crop Production. Madison, Wisc.: American Society of Agronomy.

UNDP. (2000). Drylands, people and land use, 5-16

Van Koppen, B. 2000. From Bucket to Basin: Managing River Basins to Alleviate Water Deprivation. The Contribution of the International Water Management Institute to the World Water Vision for Food and Rural Development. Colombo: International Water Management Institute

Viets, F.G., Jr. 1962. "Fertilizers and the Efficient Use of Water." Advances in Agronomy 14: 223-64.

YalewAdane 2010. Integrated Watershed Development from Sustainable Livelihood Perspective; The case of Terri Watershed in Delanta Woreda, Ethiopia.

Zewdie, M., Moti, J. and Ascimelis, G. 2007.Assessment of WendoWesha irrigation scheme in AwassaZuria. Proceddings of research project completion workshop; 2007 Feb 1-2; Addis Abaaba, Ethiopia 